\title{
Nuclear ambition
}

\author{
The US weapons labs need to develop a twenty-first-century vision of deterrence - \\ one that does not include making new bombs.
}

n $\mathrm{n}$ the past two weeks, US President Barack Obama has signed a new arms treaty with Russia, scaled back the role of the nuclear arsenal in US foreign policy and negotiated agreements to secure highly enriched uranium and other nuclear materials around the globe. Much work remains to be done, but the president has laid out a broad vision for combating twenty-first-century nuclear threats. This makes it all the more disappointing that he wasn't able to rein in remnant cold-war thinking among his own scientists at the US nuclear weapons labs.

The administration laid out its latest policy in the 6 April Nuclear Posture Review, which represents progress both in form - it is the first such review to be unclassified - and substance. In keeping with an earlier decision to abandon plans to build a reliable replacement warhead (RRW), the policy says that the United States will not pursue new weapons in the future. Yet the text contains lawyerly caveats that could allow designers to mix and match older designs, and then add non-nuclear components to produce what is effectively a brand new thermonuclear device. Indeed, some critics suggest that the cancelled RRW itself could be squeezed through these loopholes.

This was no accident. During the administration's internal debate on the review, managers of the energy department's weapon labs Los Alamos and Sandia in New Mexico and Lawrence Livermore in California - secured ambiguous language that would allow business to continue as usual. Worried about morale, recruitment and the retention of quality scientists in the weapons programme, the labs' leaders are zealously protecting the craft and its practitioners. Their argument is that scientists learn important lessons when they translate equations and simulations into reality. In addition, the labs hint that the current arsenal is so finely tuned that even minor defects resulting from ageing materials could compromise the entire system; from this perspective, a new warhead would actually be safer, more secure and have a larger margin for error.

None of these arguments can be ignored. However, they have to be weighed up in the larger strategic context — including the strong possibility that the labs' political manoeuvring could damage US credibility in its quest for global cooperation on nuclear non-proliferation. In particular, the labs' insistence on maintaining all options for managing the arsenal could undercut Obama's already dim hopes of getting the US Senate to ratify the Comprehensive Nuclear-TestBan Treaty, which has been languishing since 1996.

What is needed now is absolute clarity of purpose. Obama could achieve this with an executive order stating that the primary role of nuclear scientists will be the surveillance and maintenance of an evershrinking nuclear stockpile - a fundamental task on which the labs have come up short, according to government reports. Nuclear scientists and engineers would be able to engage in serious design efforts, backed by a modernized scientific infrastructure, but it must be abundantly clear that new designs will not move through to development.

Such an executive order would doubtless come under political attack for compromising US security. But it would be consistent with the thinking of the JASON group, a panel of independent scientific advisers to the US government who looked at this issue
"Independent scientific advisers found no evidence that current weapons could not be maintained for decades into the future." last year and found no evidence that the current weapons could not be maintained for decades into the future under the current system.

Such an order would also accelerate a gradual transformation of the US nuclear deterrent from one based on bombs and warheads held at the ready to one based on capabilities: knowledge held by nuclear scientists and engineers at the labs would help the nation to police the international non-proliferation regime and serve as a deterrent to those who pursued nuclear weapons. That kind of deterrent would be in line with the commitment to disarm that major nuclear powers have already made under the 1970 Nuclear Non-Proliferation Treaty, which is up for a five-year review next month. Just as importantly, it is a vision that a new generation of nuclear scientists and engineers would be much more likely to embrace.

environment or human health are acted on only if the Environmental Protection Agency (EPA) can uncover and prove them. The Lautenberg legislation, and complementary legislative language being drafted in the House of Representatives by Bobby Rush (Democrat, Illinois) and Henry Waxman (Democrat, California) would place the burden of proof where it belongs, requiring industries to provide a certain quantity of safety data before releasing a new chemical into wide use. It would also give the EPA the authority to request additional data from manufacturers as it deems necessary. These changes would bring the TSCA more in line with Europe's Registration, Evaluation, Authorisation and Restriction of Chemicals (REACH) legislation from 2007 (see Nature 460, 1065; 2009). 
This effort at legal reform has won applause from environmental, health and industry groups alike. If passed, the law would be a welcome step in the right direction. Although chemical companies are understandably concerned about the extra costs such testing would entail, the new framework should make navigating the regulatory waters considerably more straightforward.

But scientific reform is needed as well. For decades, regulatory bodies have relied on guideline studies conducted under national and internationally agreed standards known as Good Laboratory Practice (GLP). This governs how the studies are planned, performed, monitored, recorded, reported and archived. These standards are invaluable, providing a guarantee of reliability and cross-comparability for studies on chemical safety. But the glacial pace of consensus building and validation required to update guidelines can leave gaping holes that allow the approval of chemicals of questionable safety.

A case in point is bisphenol A (BPA), a major component of polycarbonate plastics and resins widely used in consumer products, including food-can linings and baby bottles (see page 1122). Research in laboratories around the world has now produced many studies showing cognitive, developmental and reproductive effects associated with exposure to the chemical in lab animals. But because these effects seem to be triggered through BPA's hormone-mimicking qualities, and its long-term, epigenetic influence on gene expression, they can be considerably more subtle than the ones that guideline studies were designed to look for - those arising from more clearly toxic substances such as asbestos or thalidomide. Moreover, detecting BPA's effects generally requires cutting-edge biological techniques whose results, in the eyes of regulatory bodies, carry just a fraction of the weight of those produced by a GLP study.

This situation has to change. The scientists who develop these techniques need to put a high priority on validating and standardizing them in ways that make the results usable by regulators. And regulators need to find faster ways to get the new techniques incorporated into guideline studies. If they don't, keeping pace with the increasing speed at which chemicals are being developed and introduced will be impossible. Regulators are already overwhelmed by a backlog of consumer chemicals on which there are inadequate safety data. Yet now they are also having to grapple with nanomaterials and other novel compounds that need sophisticated science to evaluate, and sophisticated laws to regulate properly.

The new US legislation, although it may take some time to be enacted, could and should be shaped to encourage such changes. Regulators should not be expected to chase down every result produced by new and unproven methods. But they should be able to take into account new methods as rapidly as they can be validated.

\section{Time for libel-law reform}

\section{Simon Singh's recent libel result is a victory for science, but the real fight lies ahead.}

ustice prevailed last week when the British Chiropractic Association abandoned its libel action against the science writer Simon Singh - but it prevailed despite, rather than because of, English libel law.

This law is unique in the burden of proof it places on those accused of libel, and in allowing such accusations to be made against almost anyone whose words can be read in England. The result is a ridiculously tilted playing field that constrains free speech and open debate around the world - scientific debate included.

Singh's case is the most high-profile example, but there have been many others. British doctor Peter Wilmshurst is being sued in England after commenting on a clinical trial of a heart device in which he was involved. Danish radiologist Henrik Thomsen was sued after he made comments about a drug used in his field. Francisco Lacerda, of Stockholm University, has seen his work on the validity of lie detectors withdrawn from publication after threats of libel action. Science writer Ben Goldacre and The Guardian newspaper fought a long and costly battle with a promoter of vitamin treatments for AIDS.

Regardless of outcome - the Thomsen suit was settled earlier this year, for example - the use of English libel law to stifle debate should concern all researchers. For every case that comes to court, say campaigners for reform, there are many more in which scientists who lack the resources to fight just quietly back down, or worse, censor themselves even before publishing.
Against this dark background there is at last some light.

Not only has the 1 April ruling in Singh's favour from England's Court of Appeal forced the British Chiropractic Association to withdraw its libel action, but the court's judgment itself may offer wider protection to scientists and writers (see go.nature.com/EQFfg3). In particular, the judgment points approvingly to a 1994 US ruling also cited by Singh's legal team: "Scientific controversies must be settled by the methods of science rather than by the methods of litigation."

Concerns about scientific freedom are also found in a recent report on libel from the UK parliamentary Culture, Media and Sport Committee: "we believe that the fears of the medical and science community are well-founded, particularly in the internet age and with the growth of 'libel tourism."

Meanwhile, Singh's brave refusal to back down in the face of a potentially ruinous suit - unusual in being targeted at him personally, rather than at the newspaper that published his article - has given birth to a grass-roots campaign for fundamental reform of the libel law. Nature has backed this campaign (see Nature 459, 751; 2009), as have many scientists who recognize that they are just one publication away from being in Singh's position.

Better still, the politicians seem to be listening. With elections coming up in May, all three of the main UK parties have included promises of libel reform in their manifestos.

As heartening as these developments are, however, fulfilment of these promises is still a long way off. Reformers will need to keep up the pressure on whoever wins the British election next month. For speech to be truly free in England, the law must be rewritten to defend not just science, but all debates carried out honestly and in the public interest. 